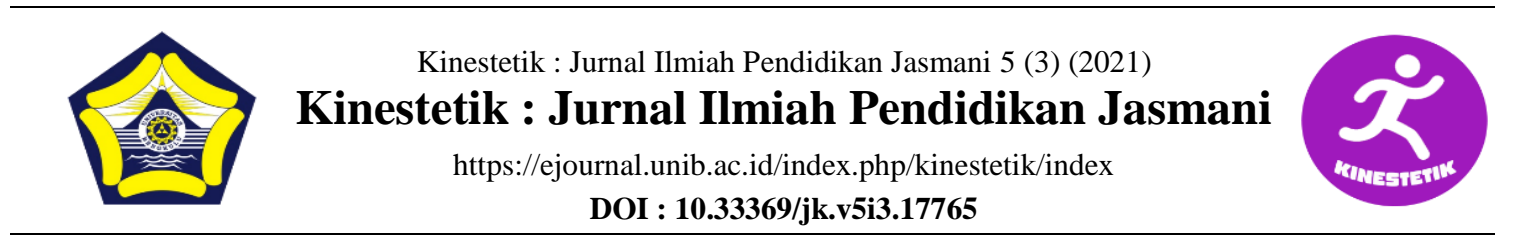

\title{
THE EFFECTIVENESS OF ONLINE PHYSICAL EDUCATION LEARNING DURING COVID-19 PANDEMIC ON STUDENTS OF SMA PLUS ALFATIMAH BOJONEGORO
}

\author{
Mohamad Da'i ${ }^{1 *}$, Hilmy Aliriad ${ }^{2}$ \\ ${ }^{12}$ Pendidikan Jasmani Kesehatan dan Rekreasi, Fakultas Keguruan dan Ilmu Pendidikan, \\ Universitas Nahdlatul Ulama Sunan Giri Bojonegoro.
}

\begin{tabular}{l} 
Article Info \\
\hline Article History : \\
Received : September 2021 \\
Revised : : September 2021 \\
Accepted : : September 2021 \\
Available online : : \\
September 2021 \\
\hline
\end{tabular}

Keywords:

Online Learning, Physical Education, Covid 19 Pandemic

\begin{abstract}
This research aims to determine the effectiveness of Online Learning Physical Education in Times of Pandemic COVID-19 on High School Students Plus Al Fatimah Bojonegoro. The type of research used is descriptive quantitative. The method used is a survey using a questionnaire instrument. The population in this study were students of class X, XI and XII with a sample of 100 students. The analysis technique uses descriptive quantitative analysis techniques with percentages. The results of this study indicate that the responses of students regarding online learning during the pandemic with the very effective category are $21 \%$, the effective category is $74 \%$, the less effective category is $5 \%$, and the ineffective category is $0 \%$. Thus, it can be concluded that the effectiveness of learning Physical Education, Sports and Health in the network (online) during the covid pandemic based on the views of SMA Plus Al Fatimah Bojonegoro students is included in the effective category.
\end{abstract}

\begin{tabular}{llr}
\hline Corresponding address & : Jalan Jendral Ahmad Yani No.10, Jambean, & ISSN 2685-6514 (Online) \\
& Sukorejo, Kec. Bojonegoro, Kabupaten & ISSN 2477-331X (Print) \\
& Bojonegoro, Jawa Timur & \\
*Corresponding email $\quad$ dai@ @ungiri.ac.id &
\end{tabular}




\section{INTRODUCTION}

On March 11, 2020, the International Health Organization (WHO) announced the status of COVID-19 as a pandemic. This requires the whole world to immediately make efforts to stop and overcome its effects. The method chosen by the Indonesian government as an effort to suppress the spread of the virus is physical restrictions or physical distancing. Restrictions cause many changes in various aspects of social, economic, cultural, and even educational life. The Indonesian Ministry of Education issued a Circular Letter of the Minister of Education and Culture No. 4 of 2020 concerning the Implementation of Policies and Education in an Emergency Period for the Spread of Corona Virus Disease (COVID-19) by closing and replacing the teaching and learning process at schools using an online system at home. Online learning, online, or distance learning aims to meet educational standards by utilizing information technology by using computer devices or gadgets that are interconnected with students and teachers as well as students and lecturers (Pakpahan and Fitriani 2020)

According to the Central Bureau of Statistics, the percentage of the population using cellular phones continues to increase, until in 2018 it reached 62.41 percent. This means that more than half of Indonesians are technology savvy and ready for change. (Pakpahan and Fitriani 2020) conducted a study entitled "Analysis of the Use of Information Technology in Distance
Learning in the Midst of the COVID-19

Corona Virus Pandemic." The implementation of distance learning in the midst of COVID-19 is very dependent on the important role of technology. The learning process can run well with information technology that has developed rapidly including E-learning, Google Class, Whatsapp, Zoom and other information media. In accordance with research conducted by (Monoarfa 2012) entitled "The Effectiveness of Online Learning for Physical Education in Sports and Health in the Time of the COVID-19 Pandemic Based on the Views of Class IV and V Students of SD Negeri 1 Binangun" who obtains online learning outcomes can run effectively.

Physical Education is a subject with a lot of physical activity such as running, throwing, hitting, and jumping. Prior to the COVID-19 pandemic, a lot of learning was carried out outside the classroom or outside school for schools that did not have a field. After this pandemic, all teaching and learning activities in schools were stopped so that the implementation of Physical Education learning turned into online learning which cannot be carried out haphazardly outside the room without complying with the health protocols that have been set by the government. The online learning media used at SMA Plus Al Fatimah Bojonegoro areapplications Zoom, Google Classroom, and Whatsapp. A previous study conducted by (Pane 2015) entitled "Effectiveness of Online Learning During a Pandemic in Physical Education Subjects for Sports and 
Health" found that online physical education learning outcomes were not effective. Therefore, the authors want to review with new research related to effective online learning methods for high school students during the pandemic.

\section{METHODS}

The research design used in this research is descriptive quantitative research. According to (Sugiyono 2016) quantitative research methods are research methods based on the philosophy of positivism to examine the population or sample of research objects. This method is used to find out the description and look for information, data and processing numbers from the results of data collection is a survey method.

\section{Participants}

According to (Sugiyono 2016), conveying the population is the scope of the generalization area consisting of: objects or subjects with certain qualities and characteristics needed by researchers and have been determined to be studied and conclusions drawn. The population that the author uses as research objects are all students of class X, XI and XII SMA Plus Al Fatimah Bojonegoro aged 15-17 years and female in the academic year 2021 - 2022 .

\section{Sampling Procedures}

Sample is part of the number and characteristics possessed by the population according to (Sugiyono 2016). The sampling technique used is probability sampling with a simple random sampling model. The number of samples of SMA Plus Al Fatimah students used in the study was 100 students. This technique is done by assuming that all samples are homogeneous or all samples have the same opportunity.

\section{Materials and Apparatus}

In this research, the instrument used is a question in the form of a series of questions that already have an answer, so that the respondent just chooses the answer that is appropriate or close to the situation he is experiencing. The scale in this study is a Likert scale. The Likert scale is used as a measuring tool for attitudes, opinions and perceptions of a person or group of people about social phenomena (Sugiyono 2016).

A good test question is a valid question that can be used to measure the ability as it is or the test results are in accordance with the actual situation. The instrument used in this study was quoted from a study (Monoarfa 2012) entitled "The Effectiveness of Online Learning for Physical Education in Sports and Health During the COVID-19 Pandemic Based on the Views of Class IV and V Students of SD Negeri 1 Binangun". The instrument was then used as a tool to search for data with thetechnique OneShot Case Study by distributing the questionnaire link that had been made to respondents through the student's whatsapp group. According to (Arikunto 2013) OneShot Case Study is a research design that only performs one-time 
treatment which is estimated to have had an effect.

Data collection techniques are an important stage in the research process to support the implementation of a research. In this study, the process of collecting data in the field by sharing a google form link that was distributed through the class WhatsApp group.

\section{Design or Data Analysis}

Analysis in this study will produce the values of each respondent's answer which will be calculated to determine the quality which is then interpreted. Changes in the average value of each aspect and category using the reference guideline for Benchmark Assessment (PAP). According to (Trimawan, Suwatra, and ... 2014) argues that in using the conversion guideline research scale for LAP, you can use a scale of four, five, nine and so on. In this study, the researcher used a scale of four based on the conversion in the following table.

Table 1 PAP Four Scale Conversion Guidelines

\begin{tabular}{ccc}
\hline No & Score & Category \\
\hline 1 & STi X Mi $+1.5 \mathrm{Sdi}$ & Very effective \\
\hline 2 & $\mathrm{Mi}+1.5 \mathrm{SDi}>\mathrm{X} \mathrm{Mi}$ & Effective \\
\hline 3 & $\mathrm{Mi}>\mathrm{X} \mathrm{Mi}-1.5 \mathrm{Sdi}$ & Less effective \\
\hline 4 & $\mathrm{Mi}-1.5 \mathrm{SDI}>\mathrm{X} \geq \mathrm{Sri}$ & Ineffective \\
\hline
\end{tabular}

After all the data has been collected then it will be grouped based on their respective categories, this is done to process the data to find the percentage using the following formula: $\mathrm{P}=\frac{F}{N} \mathrm{X} 100 \%$ Description

$$
\begin{aligned}
& \mathrm{P}: \text { number percentage } \\
& \mathrm{N} \text { : number of frequencies } \\
& \mathrm{f}: \text { frequency }
\end{aligned}
$$

The results of the processed data can be used to see the effectiveness of online learning for physical education during the COVID-19 pandemic based on the views of SMA Plus Al Fatimah Bojonegoro students.

\section{RESULTS}

Based on the results of research on the effectiveness of online learning for physical education during the COVID-19 pandemic based on the views of SMA Plus Al Fatimah Bojonegoro students. It is known from the results of the students' responses, it is concluded that they are in the effective category. The percentage data from this study in the very effective category is $21 \%$, the effective category is $74 \%$, the less effective category is $5 \%$, and the ineffective category is $0 \%$. Supporting factors that cause effective online physical education learning as written by (Andrianto Pangondian, Insap Santosa, and Nugroho 2019) must support for students to access the internet; $b$ ) Characteristics of teachers, teachers are central in the online learning process, not just technology but the application of instructional technology from teachers that can make online learning feel offline; c) Characteristics of students, students who have the basic nature of discipline and have the skills to do learning using conventional methods.

The results of the analysis of responses from students regarding the effectiveness of physical education learning in the network as an alternative 
learning during the covid pandemic SMA Plus Al Fatimah Bojonegoro are supported by five factors, namely the physical education learning objective factor, the student interest factor, the physical education learning implementation factor, the student task factor, and learning evaluation factors.

\section{Discussion Table}

The results of research on the effectiveness of physical education online learning during the COVID-19 pandemic based on the views of SMA Plus Al Fatimah Bojonegoro students were measured by 25 questions with 100 respondents. After the data was collected, the researchers got the statistical results of the minimum score assessment data $=$ 57; Maximum score $=95 ;$ Mean $=75.54$; Median $=75 ;$ Mode $=78 ;$ and Standard deviation $=8.07$. Based on the results of processing respondent data using a formula that has been determined in the research on the effectiveness of online learning of Physical Education during the COVID-19 pandemic based on the views of SMA Plus Al Fatimah Bojonegoro students, it can be categorized as follows:

Table 2 Frequency of Student Responses Effectiveness of Physical Education Learning at SMA Plus Al Fatimah Bojonegoro

\begin{tabular}{llll}
\hline Interval & Category & Total & $\mathbf{\%}$ \\
\hline $81,5-100$ & Very Effective & 21 & $21 \%$ \\
\hline $62,5-81,4$ & Effective & 74 & $74 \%$ \\
\hline $43,75-62,4$ & Ineffective & 5 & $5 \%$ \\
\hline $25-43,74$ & Ineffective & 0 & $0 \%$ \\
\hline Total & & 100 & $100 \%$ \\
\hline
\end{tabular}

Based on the results described in the table above, it is known that the results of the effectiveness of online learning for Physical Education during the COVID-19 pandemic based on the views of SMA Plus Al Fatimah Bojonegoro students get the percentage results are very effective $21 \%$, effective $74 \%$, less effective $5 \%$ and ineffective is $0 \%$. The data above are the results obtained from five factors, namely the learning objectives of physical education, student interests, implementation of physical education learning, student assignments and learning evaluation.

The results obtained are as follows:

\section{Physical Education Learning Factors}

Table 3 Physical Education Learning Factors

\begin{tabular}{clcc}
\hline Interval & Category & Total & $\boldsymbol{\%}$ \\
\hline $9-16$ & Highly Effective & 100 & $100 \%$ \\
\hline $6-8$ & Effective & 0 & $0 \%$ \\
\hline $3-5$ & Ineffective & 0 & $0 \%$ \\
\hline $1-2$ & Ineffective & 0 & $0 \%$ \\
\hline & Total & 100 & $100 \%$ \\
\hline
\end{tabular}

Based on the data processing in the table above, italready isknown the results of the respondents related to the implementation of physical education learning factors points to the results in the "very effective" category with a percentage of $100 \%$ with the number of respondents 100 children. 


\section{Student Interest Factor}

Table 4 Factors Interests of Learners

\begin{tabular}{clcc}
\hline Interval & \multicolumn{1}{c}{ Category } & Total & $\mathbf{\%}$ \\
\hline $9-16$ & Highly Effective & 100 & $100 \%$ \\
\hline $6-8$ & Effective & 0 & $0 \%$ \\
\hline $3-5$ & Ineffective & 0 & $0 \%$ \\
\hline $1-2$ & Ineffective & 0 & $0 \%$ \\
\hline & Total & 100 & $100 \%$ \\
\hline
\end{tabular}

Based on the data processing in the table above, it has been it is known that the results of the respondents related to the factors of students' interest in learning physical education showed results in the "very effective" category with a percentage of $100 \%$ with the number of respondents is 100 children.

\section{Factors of Implementing Physical Education Learning}

Table 5 Implementation Factors Physical Education Learning

\begin{tabular}{clcc}
\hline Interval & Category & Total & $\%$ \\
\hline $9-16$ & Very Effective & 20 & $20 \%$ \\
\hline $6-8$ & Effective & 70 & $70 \%$ \\
\hline $3-5$ & Less Effective & 10 & $10 \%$ \\
\hline $1-2$ & Ineffective & 0 & $0 \%$ \\
\hline & Total & 100 & $100 \%$ \\
\hline
\end{tabular}

Based on the data processing in the table above already it is known that the results of respondents related to the implementation of physical education learning factors pointed to the results in the "very effective" category with a percentage of $20 \%$, category "effective" with a percentage of $70 \%$, the category of "less effective" with a percentage of $10 \%$, and the category of "ineffective" with a percentage of $0 \%$, with a total percentage overall is $100 \%$. The data was obtained from the number of respondents 100 children and it can be concluded that the factors for implementing physical education learning are "effective" with a percentage of $70 \%$.

\section{Student Assignment Factor}

Table 6 The Task of Learners

\begin{tabular}{clll}
\hline Interval & \multicolumn{1}{c}{ Category } & Total & $\%$ \\
\hline $9-16$ & Highly Effective & 98 & $98 \%$ \\
\hline $6-8$ & Effective & 2 & $2 \%$ \\
\hline $3-5$ & Ineffective & 0 & $0 \%$ \\
\hline $1-2$ & Ineffective & 0 & $0 \%$ \\
\hline & Total & 100 & $100 \%$ \\
\hline
\end{tabular}

Based processing the data in the table above, it can be explained the results of the respondents related to the task factor of students regarding learning physical education, showing the results in the "very effective" category with a percentage of $98 \%$, the "effective" category with a percentage of $2 \%$, the "less effective" category with $0 \%$ percentage, and the "in effective" category with a percentage of $0 \%$ of the total total respondents 100 children.

\section{Learning Evaluation Factors}

Table 7 Factor Evaluation Learning

\begin{tabular}{clcc}
\hline Interval & \multicolumn{1}{c}{ Category } & Total & $\%$ \\
\hline $9-16$ & Highly Effective & 99 & $99 \%$ \\
\hline $6-8$ & Effective & 1 & $1 \%$ \\
\hline $3-5$ & Ineffective & 0 & $0 \%$ \\
\hline $1-2$ & Ineffective & 0 & $0 \%$ \\
\hline & Total & 100 & $100 \%$ \\
\hline
\end{tabular}

Based on data processing in the table above, it can be explained the results of the respondents related to the 
learning evaluation factors about Physical education learning shows the results in the "very effective" category with a percentage of $99 \%$, the "effective" category with a percentage of $1 \%$, the "less effective" category with the percentage of $0 \%$, and the category of "in effective" with a percentage of $0 \%$ of the number total of respondents 100 children.

\section{DISCUSSION}

\section{Previous Research}

(Gikas and Grant 2013) examined the effectiveness of online learning in the midst of the COVID-19 pandemic at SD Negeri Kemloko Temanggung. During the COVID-19 pandemic, learning at Kemloko Public Elementary School is online learning. However, only a few took part in learning so that they were replaced from home, or with conventional learning terms. Students learn from home with parents with collaborative learning innovations between parents and teachers. As a result, students rated online learning as effective (18\%), rated it as average (12\%), and also students rated online learning as effective (70\%). The effectiveness of online learning for Kemloko Elementary School students, namely during home learning is less effective. Because students can not interact with teachers and friends. Students who work on assignments accompanied by their parents have a little difficulty in receiving an understanding of the material so that parents have to participate in doing their children's assignments.
(Wahjuni 2021) examines the effectiveness of online distance learning during the COVID-19 pandemic in sports and health physical education subjects. The conclusion is that the COVID-19 pandemic has changed the education system in Indonesia into distance learning using online media. This is done by teachers to reduce and stop the chain of spreading Covid-19. The use of information technology in distance learning during the Covid-19 pandemic at SMP Negeri 4 Pakem was considered effective by students in terms of understanding the material, mastering the application, and understanding the material.

\section{CONCLUSION}

Based on the results of research that has been carried out and discussions about the effectiveness of online learning for Physical Education during the COVID-19 pandemic based on the views of SMA Plus Al Fatimah Bojonegoro students, it can be concluded that it has been running effectively. The very effective category is $21 \%$, the effective category is $74 \%$, the less effective category is $5 \%$ and the ineffective category is $0 \%$.

\section{ACKNOWLEDGEMENT}

We would like to thank the Principal of SMA Plus Al Fatimah Bojonegoro who has given us permission to conduct research, and also to the students of class X, XI and XII who have agreed to be samples in this study. 


\section{REFERENCES}

Andrianto Pangondian, Roman, Paulus Insap Santosa, and Eko Nugroho. 2019. "Faktor - Faktor Yang Mempengaruhi Kesuksesan Pembelajaran Daring Dalam Revolusi Industri 4.0.” Sainteks 2019 $56-60$.

Arikunto, S. 2013.Prosedur Penelitian Suatu Pendekatan Praktik. Edisi Revisi. Jakarta: PT. Rineka Cipta

Baharin, R., Halal, R., dll, 2020, Impact of Human Resource Investment on Labor Productivity in Indonesia, Iranian Journal of Management Studies, 13(1), hal. 139-164

Beni Pekei. 2016. Konsep dan Analisis Efektivitas Pengelolaan Keuangan Daerah di Era Otonomi. Buku 1.Jakarta Pusat: Taushia

Gikas, Joanne, and Michael M. Grant. 2013. "Mobile Computing Devices in Higher Education: Student Perspectives on Learning with Cellphones, Smartphones \& Social Media." Internet and Higher Education 19:18-26. doi: 10.1016/j.iheduc.2013.06.002.

Hartono, Soetanto, dkk. 2013. Pendidikan Jasmani (Sebuah Pengantar). Surabaya: Unesa University Press.

Kusuma, Wijaya. 2011. Penelitian Tindakan Kelas. Jakarta: PT Indeks.

Mahendra (2015). Filsafat pendidikan jasmani. Bandung:Universitas Pendidikan Indonesia.

Mardiasmo.(2017). Perpajakan. Yogyakarta: Andi.

Masnur, M. (2014). KTSP Pembelajaran Berbasis Kompetensi Dan Konsektual. Jakarta: Bumi Aksara

Monoarfa, Heryanto. 2012. "Efektivitas Dan Efisiensi Penyelenggaraan Pelayanan Publik: Suatu Tinjauan Kinerja Lembaga Pemerintahan.” Jurnal Pelangi Ilmu 5(1):1-9.

Nurgiyantoro, B. (2012). Penilaian
Pembelajaran Bahasa. Yogyakarta: BPFE.

Pakpahan, Roida, and Yuni Fitriani. 2020. "Analisa Pemafaatan Teknologi Informasi Dalam Pemeblajaran Jarak Jauh Di Tengah Pandemi Virus Corona Covid-19.” JISAMAR (Journal of Information System, Applied, Management, Accounting and Researh) 4(2):30-36.

Pane, Bessy Sitorus. 2015. "Peranan Olahraga Dalam Meningkatkan Kesehatan.” Jurnal Pengabdian Kepada Masyarakat 21(79):1-4.

Sugiyono. (2016). Metode Penelitian kuantitatif. Bandung: Alfabe

Trimawan, I. K., I. I. W. Suwatra, and ... 2014. "Penerapan Model Quantum Teaching Untuk Meningkatkan Hasil Belajar IPA.” Mimbar PGSD ....

Wahjuni, Firgiawan Setyanto;Endang Sri. 2021. "Jurnal Pendidikan Olahraga Dan Kesehatan Volume 09 Nomor 02 Tahun 2021." Pendidikan Jasmani Kesehatan Dan Rekreasi 09. 